\title{
The role of macrophages in the pathogenesis of inflammatory bowel disease
}

YR MAHIDA MD, MRCP

YR MAHIDA. The role of macrophages in the pathogenesis of inflammatory bowel disease. Can J Gastroenterol 1993; 7(2):83-86. Normal intestinal macrophages are a heterogenous population of cells with phenotype possibly related to distinct functions. The increase in the mucosal population of macrophages in inflammatory bowel disease is derived from circulating monocytes which may have an enhanced capacity to perform a number of functions such as respiratory burst activity, production of cytokines such as interleukin (IL) - 1, IL-8 and possibly also antigen presenting activity. These activities (as well as others which remain to be characterized) may play an important role in the pathogenesis of Crohn's disease and ulcerative colitis.

Key Words: Crohn's disease, Cytocynes, Dendritic cells, Interleukins, Macrophages, Ulcerative colitis

\section{Rôle des macrophages dans la pathogenèse de la maladie} \section{intestinale inflammatoire}

RÉSUMÉ: Les macrophages intestinaux normaux sont une population hétérogène de cellules dont le phénotype est possiblement lié à des fonctions distinctes. L'augmentation de la population de macrophages au sein de la muqueuse dans la maladie intestinale inflammatoire est dérivée des monocytes circulants qui peuvent être dotés d'une capacité accrue à accomplir certaines fonctions au plan de la respiration cellulaire, de la production de cytokines comme l'interleukine (IL)-1, IL-8 et possiblement également d'une activité antigénique. Ces activités (et d'autres qu'il reste à découvrir) peuvent jouer un rôle important dans la pathogenèse de la maladie de Crohn et de la colite ulcéreuse.

Gastrointestinal Unit, Massachusetts General Hospital, Boston, USA

Correspondence and reprints: Dr YR Mahida, Division of Therapeutics, University Hospital, Queen's Medical Centre, Nottingham NG7 2UH, United Kingdom
$\mathrm{M}$ ACROPHAGES ARE DERIVED PREdominantly from circulating monocytes which migrate into tissues. The functions of these cells can be divided broadly into three categories. First, they have a large capacity to produce a variety of molecules with a broad range of biological activities. Secondly, they can process and present antigens to $T$ cells to initiate immunological responses. Thirdly, they are also highly phagocytic cells capable of ingesting microbes and their products as well as other molecules.

There is an increase in the mucosal population of macrophages in inflam. matory bowel disease (IBD) which, in the form of granulomata, are particularly prominent in Crohn's disease. There is much less information on human intestinal macrophages than other intestinal cell populations and some of the studies on these cells in normal individuals and IBD patients are reviewed. In the intestine, these cells are a heterogenous population which have been studied in situ in tissue sections; subsequently functional studies have been performed on isolated cells. 


\section{STUDIES ON MACROPHAGES IN SITU IN NORMAL BOWEL}

Peyer's patches: Immune responses in the gut are thought to be initiated in Peyer's patches and macrophages are likely to be involved in this process. Studies using monoclonal antibodies and histochemical stains have identified subpopulations of these cells in these regions (1). A distinct subpopulation is present in the dome region, close to the surface epithelium, in a site where they are likely to encounter antigens taken up by microfold cells. Other subsets are present in the germinal centre and interfollicular region. The latter cells are phenotypically similar to interdigitating cells of the paracortical $\mathrm{T}$-dependent regions of lymph nodes.

Lamina propria: Macrophage heterogeneity is also seen in the lamina propria of normal small and large intestine $(2,3)$. Macrophages below the surface epithelium tend to be large and round, with strong acid phosphatase activity, whereas those in deeper lamina propria are smaller with more processes and weak acid phosphatase activity. There are also differences in phenotypes of macrophages between the small and large intestine; in the former, smaller cells with weaker acid phosphatase activity but stronger ATPase activity prevail, compared to the latter (2). It is likely that these phenotypic differences are related to their different functional requirements which may be related to differences in the luminal contents.

\section{STUDIES ON MACROPHAGES IN SITU IN ACTIVE IBD}

In active IBD, macrophages with strong acid phosphatase activity are present throughout the lamina propria, and also in the submucosa in Crohn's disease. Using a panel of monoclonal antibodies, three subpopulations of macrophages have been identified that are present in the lamina propria of the mucosa with active IBD but absent or only rarely present in the normal mucosa. These subpopulations were identified with the monoclonal antibodies RFD9 to FcRIII (CD16) and to interleukin-2 (IL-2) receptor.
RFD9 positive macrophages: In the normal intestine, this antibody only labelled macrophages in the germinal centres of Peyer's patches. In active IBD, RFD9 positive macrophages were seen in the lamina propria (3-5) and were present in clusters, especially in Crohn's disease. RFD9 positive cells have also been seen in the inflamed mucosa of pouches (constructed after colectomy for ulcerative colitis) (6) but not in celiac disease (7) or bacterial colitis. Thus, studies to date suggest that RFD9 positive macrophages are seen only in the lamina propria of the mucosa with active IBD. It can be postulated that the clusters of RFD9 positive macrophages in Crohn's disease may go on to form granulomata.

Macrophages expressing FcR III: Surface labelling of macrophages with the anti-FcR III antibody (CD16) was seen in the lamina propria of mucosa with active IBD (but not normal mucosa). Animal studies suggest that cells expressing these low affinity IgG receptors may be involved in taking up and clearing immune complexes (8), and the mucosal macrophages in IBD may be performing a similar function.

Macrophages expressing receptors for IL-2: Using an enhanced alkaline phosphatase antialkaline phosphatase technique, many IL -2 receptor positive cells have been demonstrated in the mucosa with active IBD (9). These cells had morphological appearances of lymphocytes and macrophages. Identity of the latter was confirmed by studies on isolated cells (which also showed that these cells are in an enhanced state of activation). Using a similar technique, Choy et al have subsequently also reported the presence of IL-2 receptor positive cells in the mucosa with active ulcerative colitis and Crohn's disease and have confirmed the identity of the other population of cells to be $\mathrm{T}$ cells (10).

Studies on Crohn's granulomata: Heterogeneity of macrophages in and around granulomata has also been demonstrated (11). Epithelioid cells and giant cells were labelled with the antibody RFD9 but not RFD7, whereas macrophages in the surrounding lamina propria were usually RFD7-positive but
RFD9 negative. The epithelioid cells expressed IL-2 receptors and were strongly acid phosphate activity positive. Double staining studies showed that the epithelioid cells were closely associated with CD4 positive (helper) T cells whereas CD8 positive cells were much fewer in number and located mainly at the periphery. Thus, Crohn's granulomata comprise collections of cells of distinct phenotypes which are likely to be constantly interacting with each other.

\section{FUNCTIONAL STUDIES ON ISOLATED MACROPHAGES}

Respiratory burst activity: Compared to a resting cell, an activated macrophage has an enhanced capacity to perform a number of functions which include secretion of oxygen radicals and enzymes (such as neutral proteases and acid hydrolases). There is an associated increased expression of major histocompatibility complex (MHC) class II molecules and downregulation of mannose receptors on the cell surface. Activation of macrophages may occur in response to microorganisms and their products or interferon gamma (secreted by $\mathrm{T}$ cells) and allows the cell to mediate antimicrobial and cytotoxic effects (12).

In order to determine the activation phenotype of intestinal macrophages, the capacity of the isolated cells to undergo a respiratory burst (as assessed by conversion of the dye nitroblue tetrazolium to a blue brown reaction product) was studied (13).

Opsonised zymosan and phorbol myristate acetate were used to trigger the release of oxygen radicals. The majority ( $80 \%$ or more) of isolated normal intestinal macrophages did not demonstrate release of oxygen radicals. In contrast, a significantly increased proportion of macrophages from the intestine of patients with IBD were able to undergo a respiratory burst, suggesting that they were activated.

When the normal intestinal macrophages were stimulated with interferon-gamma (normally a very potent activator of macrophages), significant proportions of the cells were still unable to release oxygen radicals. This 
suggests that the majority of the normal intestinal tissue macrophages are downregulated with respect to this function and that the cells with increased capacity to release oxygen radicals are derived predominantly from monocytes which have recently migrated into the mucosa. Oxygen radicals produced by activated macrophages may also contribute to tissue damage in the mucosa.

Antigen presenting activity: Studies in mice have shown that dendritic cells are the most potent antigen presenting cells and that these cells may be distinct from macrophages. In order to characterize cells with potent antigen presenting activity in the human intestinal mucosa, isolated mononuclear cells were studied (14). Their capacity to induce proliferation of highly purified, resting, allogeneic, peripheral blood $\mathrm{T}$ cells was used to assess antigen presenting activity. This activity in isolated mononuclear cells was reduced upon depletion of macrophages (by adherence to fibronectin and panning using a macrophage specific monoclonal antibody). In contrast, the fibronectin adherent cells (which are enriched for macrophages) had enhanced antigen presenting activity. During the mixed lymphocyte reactions, clusters were shown to contain cells with a dendritic morphology which were closely associated with proliferating $T$ cells. The cells with dendritic morphology were strongly positive for human lymphocyte an-

\section{REFERENCES}

1. Mahida YR, Patel S, Jewell DP. Mononuclear phagocyte system of human Peyer's patches: An immunohistochemical study using monoclonal antibodies. Clin Exp Immunol 1989;75:82-6.

2. Selby WS, Poulter LW, Hobbs S, Jewell DP, Janossy G. Heterogeneity of HLA-DR positive histiocytes in human intestinal lamina propria: a combined histochemical and immunohistological analysis. J Clin Pathol. 1983;36:379-84.

3. Mahida YR, Patel S, Gionchetti P, Vaux D, Jewell DP. Macrophage subpopulations in lamina propria of normal and inflamed colon and terminal ileum. Gut 1989;30:826-34.

4. Gionchetti P, Mahida YR, Patel S, Jewell DP. Macrophage and tigen DR (HLADR) and also expressed antigens specific for macrophages. It was concluded therefore that cells with potent antigen presenting activity in the intestinal mucosa have characteristics of both dendritic cells and macrophages.

Cells isolated from mucosa with active IBD were shown to have enhanced antigen presenting activity compared to mononuclear cells from normal mucosa.

IL- $1 \beta$ production: IL- 1 is a cytokine with a wide range of biological properties which may play an important role in the pathogenesis of IBD (15). Monocytes and macrophages are the main source of this cytokine of which IL- $1 \beta$ is the predominant secreted from.

In vitro culture of mononuclear cells isolated from intestinal mucosa with active IBD have been shown to produce significantly greater amounts of IL- $1 \beta$ than cells from normal mucosa (16). Depletion studies (by panning) showed that macrophages were the predominant producers of this cytokine in the intestine. Culture of mononuclear cells from normal mucosa in the presence of lipopolysaccharide (a very potent stimulant of IL -1 production by monocytes) did not result in any increase in the production of IL-1 $\beta$, whereas there was an increase in the amount of the cytokine produced by cells from the inflamed mucosa. As for studies on respiratory burst activity,

lymphocyte subpopulations in magnifying endoscopic lesions of Crohn's disease. Clin Exp Immunol 1988;72:373-6.

5. Allison MC, Cornwall S, Poulter LW, Dhillon AP, Pounder RE. Macrophage heterogeneity in normal colonic mucosa and in inflammatory bowel disease. Gut 1988;29:1531-8.

6. De Silva HT, Jones M, Prince C. Kettlewell M, Mortensen NJ, Jewell DP. Lymphocyte and macrophage subpopulations in pelvic ileal pouches. Gut 1991;32:1160.

7. Mahida YR, Gallagher A, Kurlak L, Hawkey CJ. Macrophages in normal and coeliac duodenal mucosa. Gastroenterology 1990;98:A461.

8. Clarkson SB, Kimberley RP, Valinsky et al. Blockage of clearance of immune complexes by anti-Fc-gamma receptor this suggests that the normal intestinal tissue macrophages are downregulated and that the enhanced production of IL-I $\beta$ in IBD is derived from monocytes which have recently migrated into the mucosa.

Studies on tissue homogenates have confirmed enhanced in vivo production of IL-1 $\beta$ in the mucosa of patients with active $\operatorname{IBD}(17,18)$.

Studies on IL-6 and IL-8: Recent studies on IL-6 and IL-8 (which can be secreted macrophages) in IBD suggest that macrophages may have different functional capacities in ulcerative colitis and Crohn's disease. Higher circulating levels of IL- 6 have been found in active Crohn's disease compared to ulcerative colitis by three groups independently (19-21).

Higher tissue levels of IL- 8 have been demonstrated in the mucosa of patients with active ulcerative colitis compared to active Crohn's disease. Patients with active ulcerative colitis also had high circulating levels of antibodies to IL-8, but this was not the case in patients with active Crohn's disease where the levels were similar to normal controls (22). IL-8 is a very potent chemoattractant for neutrophils and the high mucosal levels in active ulcerative colitis may explain the characteristic predominance of neutrophils in this condition. The role of macrophages in the differential production of these cytokines in ulcerative colitis and Crohn's disease remains to be determined.

monoclonal antibody. J Exp Med 1986;164:474-89.

9. Mahida Y R, Wu K, Patel S, Jewell DP. IL-2 receptor expression by macrophages in inflammatory bowel disease. Clin Exp Immunol 1988;74:382-6.

10. Choy MY, Walker-Smith JA, Williams CB, MacDonald TT. Differential expression of CD25 (interleukin 2 receptor) on lamina propria $T$ cells and macrophages in the intestinal lesions in Crohn's disease and ulcerative colitis. Gut 1990;31:1365-70.

11. Mahida YR, Patel S, Jewell DP. Macrophage and lymphocyte subpopulations in the granuloma of Crohn's disease. In: MacDermott RP, ed. Inflammatory Bowel Disease: Current Status and Future Approach. Amsterdam: Elsevier Science Publishers BV, 1988:137-41. 
12. Adams DO, Hamilton TA. The cell biology of macrophage activation. Ann Rev Immunol 1984;2:283-318.

13. Mahida YR, Wu K, Patel S, Jewell DP. Respiratory burst activity of intestinal macrophages in normal and inflammatory bowel disease. Gut 1989:30:1362-70.

14. Mahida YR, Wu K, Jewell DP. Characterization of antigen presenting activity of mononuclear cells isolated from normal and inflammatory bowel disease colon and ileum. Immunology 1988;65:543-9.

15. Cominelli F, Nast CC, Clark BD, Schindler R, Llerena R, Eysselein VE, Thompson RC, Dinarello CA. Interleukin-1 (IL1) gene expression, synthesis and effect of specific receptor blockade in rabbit immune complex colitis. J Clin Invest 1990;86:972-80.

16. Mahida YR, Wu K, Jewell DP. Enhanced production of interleukin $1 \beta$ by mononuclear cells isolated from mucosa with active ulcerative colitis or Crohn's disease. Gut 1989;30:835-8.

17. Mahida YR, Lamming CED, Gallagher A, Hawthorne AB, Hawkey CJ. 5 -aminosalicylic acid is a potent inhibitor of ILI $\beta$ production in organ culture of colonic biopsies from patients with inflammatory bowel disease. Gut 1991;32:50-4.

18. Ligumsky M, Simon PL, Karmeli FC, Rachmilewitz D. Role of interleukin-1 in inflammatory bowel disease enhanced production during active disease. Gut 1990;31:686-9.
19. Mahida YR, Kurlak L, Gallagher A, Hawkey CJ. High circulating levels of interleukin 6 in active Crohn's disease but not ulcerative colitis. Gut 1991;32:1531-4.

20. Gross V, Andus T, Caesar I, Roth M, Scholmerich J. Evidence for continuous stimulation of interleukin-6 production in Crohn's disease. Gastroenterology 1992;102:514-9.

21. Lobo AJ, Jones SC, Evans SW, Banks R, Rathbone BJ, Axon ATR. Plasma interleukin 6 in inflammatory bowel disease. Gut 1990;31:All94.

22. Mahida YR, Ceska M, Effenberger F, Kurlac L, Lindley I, Hawkey C]. Enhanced synthesis of NAPI/IL 8 in active ulcerative colitis. Clin $\mathrm{Sci}$ $1992 ; 82: 273-5$ 


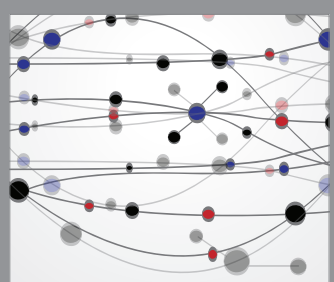

The Scientific World Journal
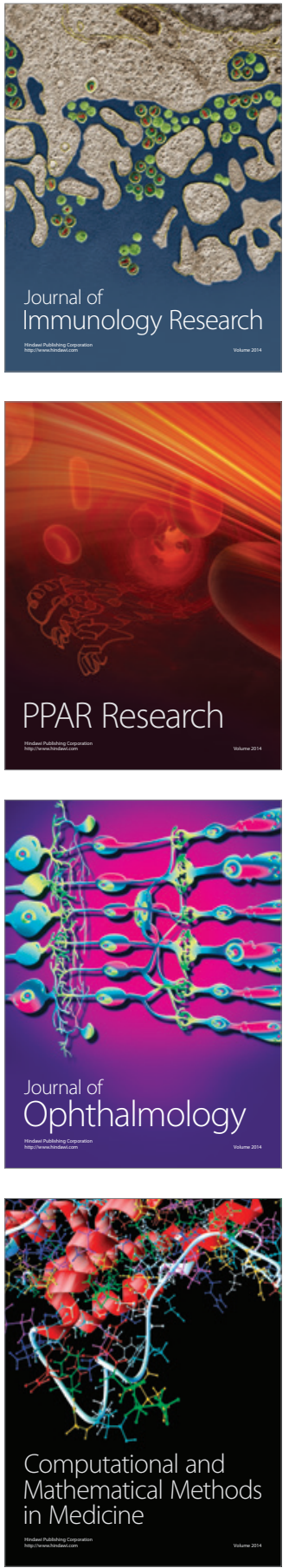

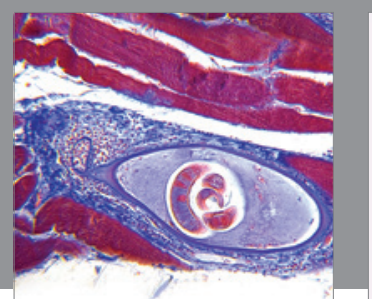

Gastroenterology Research and Practice

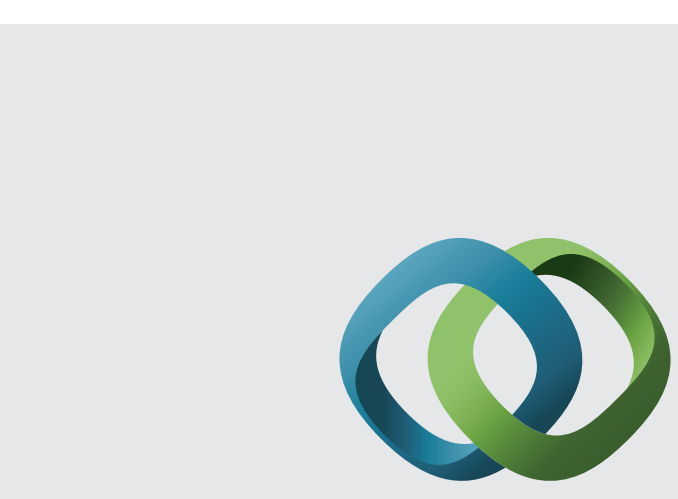

\section{Hindawi}

Submit your manuscripts at

http://www.hindawi.com
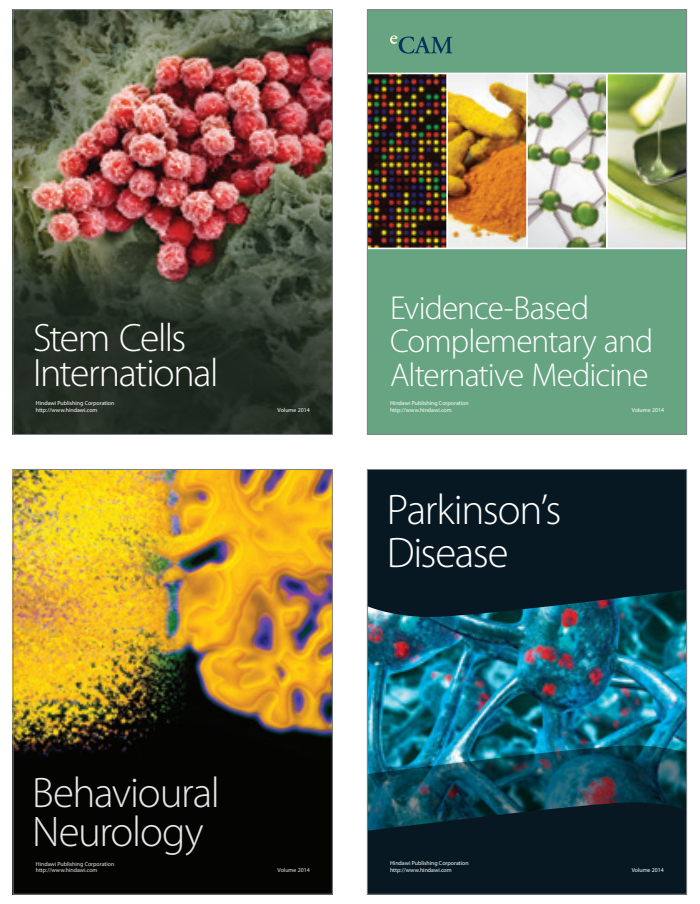
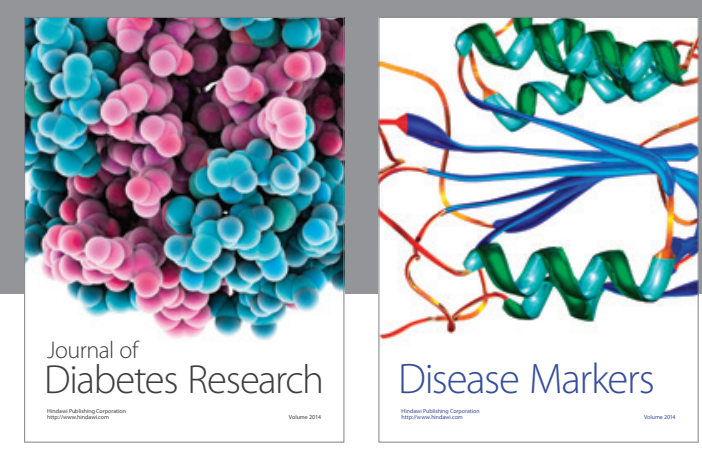

Disease Markers
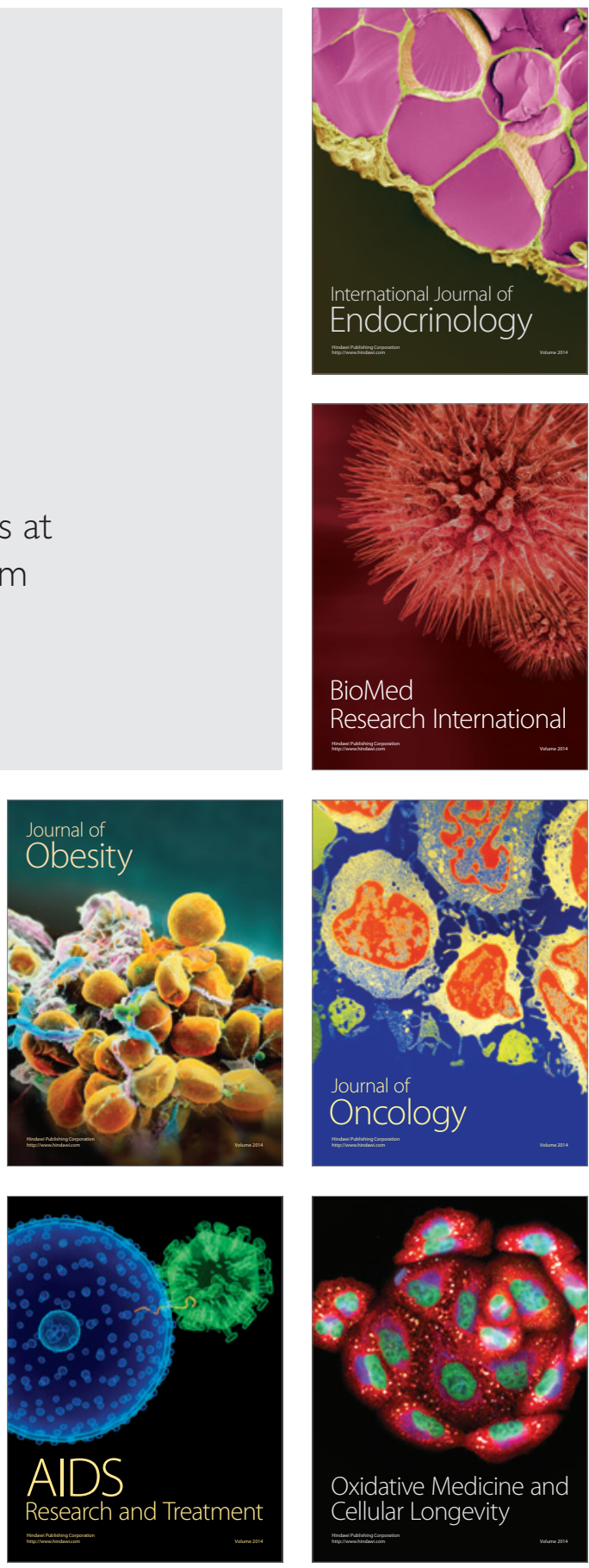